\title{
SUPPLEMENTATION OF BUTTERMILK WITH RED BEET ROOT FOR PRODUCING FERMENTED MILK BEVERAGE
}

\author{
MOHAMMED I. HASHEM
}

\author{
Dairy Microbiology Department, Animal Production Institute, Agriculture \\ Research Centre, Dokki, Giza, Egypt.
}

(Manuscript received 24 April 2018)

\begin{abstract}
$\mathrm{T}$ his study aimed to produce new natural products from butter milk supplemented with probiotic and Red beet root (Beta vulgaris L.). Red beet root (RBR) used as health promoting ingeredient scontaining vitamins, minerals, antioxidants and fibers. Natural fermented buttermilk beverage were prepared by adding different levels of (RBR) puree $(0,5,10$, and $15 \% \mathrm{v} / \mathrm{v})$, $2 \%$ sugar and $0.15 \%$ CMC. Buttermilk fortified with (RBR) puree was characterized by increasing values of total carbohydrate, fiber, viscosity, total phenol compounds (PC), antioxidant activity\%, Flow time and organoleptic properties. also, it was found suitable to support the growth of probiotic strains, namely: Lactobacillus acidophilus, Lactobacillus bulgaricus, Streptococcus thermophilus. While the values of $\mathrm{pH}$, whey syneresis, total bacterial count, moulds \& yeast count were increased. All treatments were organoleptically acceptable and the buttermilk containing $10 \%$ (RBR) showed superior sensory properties compared to the control followed by that containing $15 \%$ (RBR). Successfully natural beverage prepared from butter milk supplemented with (RBR) characterized by high nutritional value, high acceptability and could be used as formulate synbiotic dairy drinks.
\end{abstract}

Key words: buttermilk, Red Beet Root, probiotic, dairy functional food.

\section{INTRODUCTION}

The global probiotic market size has increased rapidly in the last years, and the yoghurt and fermented milk beverage sector accounts for the highest market share in this area. There is a growing demand for development of new yoghurt-like probiotic foods (Vinderola,C.,G. , et al. 2002). Fermented milks or beverages offer an attractive food-based delivery vehicle for probiotic cultures, and fruity or cerealbased ingredients are new trends for development of probiotic dairy products, particularly the use of high-phenolic containing fruit juice as a medium for probiotics (Ozcon T., et al. 2013). The effects of the fruity food matrices on the probiotic survival activity and a positive effect of this interaction in the host are important approaches for many studies. 
The well -documented health benefits of a diet high in fruit and vegetable has led to a growing interest in so called functional foods. In recent years the red beet root has attracted much attention as a health promoting food .

Red beet roots ( Beta vulgaris L.) are rich in valuable active compounds such as carotenoids, glycine . saponins, betacyanines, folates, betalain, polyphenols and flavonoids (Vali, L., et al. 2007). Beet pigments, betalains, have been examined as natural colorants in food products such as processed meat, ice cream , baked goods, candies, and yogurt. Beet root juice contains a high level of biologically accessible antioxidants as well as many other health promoting compounds such as potassium, magnesium, folic acid, iron, zinc, calcium, phosphorus, sodium, niacin, biotin,Vit. B6 and soluble fiber (Wootton-Beard, et al. 2011 ). Beet roots are the main commercial source of betalains (concentrate or powder) in the food industry, with the use of betanin restricted as a natural by added to different foods like gelatins, desserts in general, confectionery, dry mixes, dairy products, beef and chicken derived products (Delgado-Vargas et al. 2000).

Buttermilk, is the by-product of butter-making process, has an overall composition and appearance very similar to that of skim milk, but differs from skim milk in its high content of fat and milk fat globule membrane (MFGM) components. This aqueous phase of buttermilk contains most of the water-soluble components found in cream. Buttermilk represents a significant volume for the dairy industry by-products. For these reasons, buttermilk has attracted attention as a source of high added-value ingredients over the past decade (Conway et al., 2013 ). One of the approaches for its utilization is that use as a medium to support the growth of probiotic strains and to formulate symbiotic fermented dairy drinks .A few well-controlled clinical trials provided evidences for the buttermilk healthpromoting benefits (Baumgartner. et al., 2013; and Conway et al., 2014).

Due to the above mentioned health benefits of (RBR); the aim of this study was come up to develop a symbiotic buttermilk beverage supplemented with (RBR) to enhanced functional properties.

\section{MATERIALS AND METHOD}

\section{Materials:}

Sweet butter buffalo's milk ( $0.65 \%$ fat) was obtained from Animal Production Research Institute, Egypt. Youghurt starter culture consists of Streptococcus salvaricus sub sp. thermophilus and Lactobacillus delbreuckii sub sp. bulgaricus was obtained from Cairo MIRCEN culture collection center, Faculty of Agriculture, Ain-Shams University. Pure lyophilized Direct Vat Set (DVS) cultures of L. acidophilus 
LA-5 obtained from Chr. Hansen Lab., Copenhagen, Denmark Red beet root (RBR) (Beta vulgaris L.) and sugar were obtained from local market at Cairo, Egypt. Sodium carboxy methyl cellulose (CMC) was obtained from Misr Food Additives. MIFAD

Table 1. The chemical composition of buttermilk and (RBR) pureeused in the present study.

\begin{tabular}{|c|c|c|}
\hline Character assessed & Butter milk & (RBR) puree \\
\hline Dry matter & 9.55 & 87.2 \\
\hline Fat & 0.65 & 1.08 \\
\hline Protein & 3.54 & 7.61 \\
\hline Ash & 0.74 & 5.82 \\
\hline Fiber & - & 14.4 \\
\hline Available Carbohydrates \% & 4.52 & 54.29 \\
\hline $\mathbf{P h}$ & 6.71 & - \\
\hline$(\mathrm{mg} / 100 \mathrm{~g})$ & 156.1 & 21.4 \\
\hline$P(\mathbf{m g} / 100 \mathrm{~g})$ & 92 & - \\
\hline$\beta$-carotene $\quad(\mathrm{mg} / \mathbf{1 0 0 g})$ & - & 35.3 \\
\hline
\end{tabular}

\section{Experimental procedures:}

\section{Preparation of bacterial starter culture:}

Lyophilized bacterial culture was inoculated in previously autoclaved skim milk at $\left.\left(121^{\circ} \mathrm{C} / 15 \mathrm{~m}.\right)\right)$ and incubated at $37^{\circ} \mathrm{C}$.

\section{Preparation of (RBR) puree:}

Cooked Red beet root puree was prepared by soaking the cleaned small pieces of red beet root in water ( $1 \mathrm{~kg}$ sugar beet / $200 \mathrm{ml}$ water) and boiled for $10 \mathrm{~min}$ , then the mixture ( red beet and water) was minced and blended to get very fine paste and kept frozen until used, as described by (El-dardiry. et al. 2011) . 


\section{Manufacture of natural buttermilk beverages:}

Manufacture of buttermilk beverages was carried out according to the flow diagram show in Figure (1)

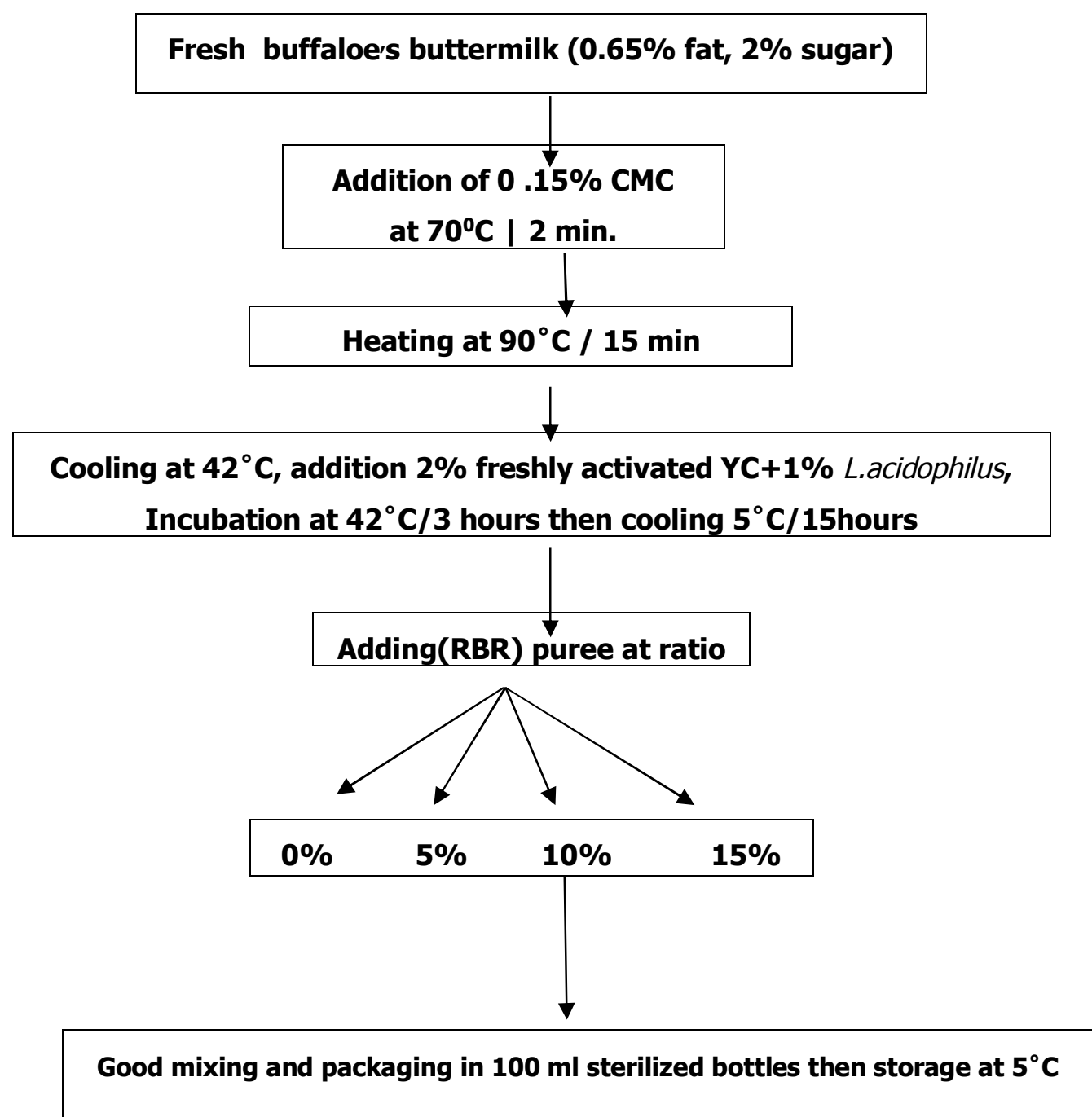

Fig. 1. Flow diagram of manufacturing buttermilk beverages like product

\section{Analytical methods}

Dry matter, fat, ash and total nitrogen of fermented buttermilk beverage were determined according to ( AOAC 2007). The $\mathrm{pH}$ value was measured using Lab. $\mathrm{pH}$ meter with a combined electrode, Hanna digital $\mathrm{pH}$ meter. The viscosity of buttermilk beverage was measured by Brookfield DV- E viscometer using spindle 4 at rpm 20 in $200 \mathrm{ml}$ of buttermilk sample. The temperature was maintained at $25^{\circ} \mathrm{C}$ and viscosity value was expressed in centi poises (cp). Flow time of the buttermilk beverages were measured as the time in seconds required to discharging a50ml pipette at $5 \mathrm{C}^{0}$ under atmosphere pressure (Arbuckle 1986). Fiber content of buttermilk 
was determined as described by (AOAC 2007). Total phenolics (TP) was analysed using Folin-Ciocalteu method as described by Jayaprakasha et al. 2001. The mineral contents were determined according to the method described by the (AOAC 2007) using atomic absorption spectrometer. Folates content were determined as mentioned by (Holt et al. 1988). Syneresis (amount of whey exhausted) was measured as described by Mehanna and Mehanna 1989. Carbohydrate content of all samples was calculated as described by Ceirwyn, 1995 using the following formula:

Carbohydrates $\%=100-($ fat $\%+$ protein $\%+$ ash $\%+$ fiber $\%+$ moisture $\%)$.

\section{Microbiological analyses}

Total bacterial count moulds and yeasts count were determined according to Standard Methods for Examination of Dairy Products (APHA, 1994).

Str. thermophiles, $L b$. acidophilus and $L b$.bulgaricus were enumerated using M17 agar, MRS-saline agar respectively after the incubation at $37^{\circ} \mathrm{C}$ for 72 h. as reported by Dave and Shah 1996.

\section{Antioxidant Activity:}

The antioxidant activity assay was evaluated by using DPPH (2,2-diphenyl-1picryl hydrazyl ) according to the method of (Shimada. et al.. 1992). Sample extract was added to $1.0 \mathrm{~mL}$ of $0.01 \%$ methanolic solution of DPPH, and absorbance using spectrophotometer type Shimadzu UV 240.was measured at $517 \mathrm{~nm}$ after $30 \mathrm{~min}$. The percent of inhibition was calculated against a control using formula as follow:

Inhibition $\%=$ A control 517- A sample $517 \times 100$

\section{( A control 517)}

\section{Sensory evaluation :-}

The organoleptic properties of buttermilk beverages were evaluated by a taste panel of 12 panelists from Dairy Microbiology and Dairy Technology Departments, Animal Production Research Institute, according to ( Deka et al. 1984).

\section{Statistical analysis :}

The results obtained (mean of three replicates) were statistically analyzed according to statistical analyses system user's guide (SAS, 1996).

\section{RESULTS AND DISCUSSION}

\section{Chemical composition of fermented butter milk beverages:}

Chemical composition of butter milk and (RBR) puree before preparation is shown in Table ( 1 ). 
Data presented in Table (2) summarize the chemical composition of fermented butter milk beverage. Addition of (RBR) had remarkable effect on the TS, carbohydrate, protein , ash , and fiber .

TS. content varied between 13.16 to $24.25 \%$, The highest value with recorded with T4 (15\%) From these data, it was easy to detect that the control treatment characterized by their low TS, protein ,ash , fiber and carbohydrates contents in comparison with other treatments .

These variation could be attributed to the high TS., protein and carbohydrates content in (RBR) puree. In addition these values increased with increasing the ratio of (RBR) puree.

Table 2. Chemical composition of buttermilk beverage fortified with different levels of (RBR)

\begin{tabular}{|l|c|c|c|c|}
\hline \multirow{2}{*}{ Items (\%) } & \multicolumn{4}{|c|}{ Treatments } \\
\cline { 2 - 5 } & Control & T1 & T2 & T3 \\
\hline Dry matter & 13.16 & 16.87 & 20.56 & 24.25 \\
\hline Fat & 0.65 & 1.02 & 1.04 & 1.06 \\
\hline Protein & 3.55 & 3.75 & 3.94 & 4.15 \\
\hline Ash & 0.77 & 1.02 & 1.27 & 1.54 \\
\hline Fiber & - & 0.73 & 1.45 & 2.17 \\
\hline $\begin{array}{l}\text { Available } \\
\text { Carbohydrates }\end{array}$ & 4.8 & 10.31 & 14.86 & 16.37 \\
\hline
\end{tabular}

Tretments.. Control $=0 \%$ (RBR) puree.

$$
\begin{aligned}
\mathrm{T} 1 & ==5 \%(\mathrm{RBR}) \text { puree. } \\
\mathrm{T} 3= & =15 \%(\mathrm{RBR}) \text { pur }
\end{aligned}
$$

$\mathrm{T} 2==10 \%(\mathrm{RBR})$ puree.

\section{pH value:}

It is obvious from the results in Table (3) that, the supplementing with (RBR) lead to significant differences $(\mathrm{P}<0.001)$ in $\mathrm{pH}$ value of resultant fermented buttermilk beverage. It was noticed that the treatments with (RBR) had higher $\mathrm{pH}$ value when fresh and during the storage period than control. 
Table 3. pH of buttermilk beverages fortified with different levels of (RBR) (Average of three replicates

\begin{tabular}{|c|c|c|c|c|}
\hline \multirow{2}{*}{$\begin{array}{c}\text { Cold storage } \\
\text { period } \\
\text { (weeks) }\end{array}$} & Contro & $\mathbf{T}$ & $\mathbf{T}$ & Treatments \\
\cline { 2 - 5 } & & & & \\
\hline $\mathbf{0}$ & $4.59^{\mathrm{d}, \mathrm{a}}$ & $4.61^{\mathrm{c}, \mathrm{a}}$ & $4.64^{\mathrm{b}, \mathrm{a}}$ & $4.65^{\mathrm{a}, \mathrm{a}}$ \\
$\mathbf{1}$ & $4.32^{\mathrm{d}, \mathrm{a}}$ & $4.55^{\mathrm{c}, \mathrm{a}}$ & $4.58^{\mathrm{b}, \mathrm{a}}$ & $4.60^{\mathrm{a}, \mathrm{a}}$ \\
$\mathbf{2}$ & $4.14^{\mathrm{d}, \mathrm{b}}$ & $4.31^{\mathrm{c}, \mathrm{b}}$ & $4.41^{\mathrm{b}, \mathrm{b}}$ & $4.44^{\mathrm{a}, \mathrm{b}}$ \\
$\mathbf{3}$ & $4.03^{\mathrm{d}, \mathrm{c}}$ & $4.10^{\mathrm{c}, \mathrm{c}}$ & $4.14^{\mathrm{b}, \mathrm{c}}$ & $4.19^{\mathrm{a}, \mathrm{c}}$ \\
\hline
\end{tabular}

The letters before comma possess the factor of( RBR) level. While those after comma possesses the storage period of buttermilk. The means with the same letter at any position did not significantly differ $(P>0.05)$.

\section{Microbiological quality:}

It is obvious from results in Table (4) that, there are reverse relationships between total bacterial count and additional levels of (RBR). This might be due to the biological active compounds from (RBR) which exhibited antimicrobial activity. The active compounds are based on phenolic compounds (flavonoid, $\beta$ carotene, phenols). This finding is in coincidence with those reviewed by Kawase et al. 2013.

Molds and yeast were not detected in all treatments when fresh and during storage period. However, molds and yeast appeared only in the control after 3 weeks.

Table 4. Microbiological quality (log CFU/ mL) of beverages Buttermilk supplemented with different levels of (RBR).

\begin{tabular}{|c|c|c|c|c|}
\hline \multirow{2}{*}{$\begin{array}{c}\text { Cold storage } \\
\text { period } \\
\text { (weeks) }\end{array}$} & \multicolumn{4}{|c|}{ Treatments } \\
\hline & Control & T1 & $\mathbf{T 2}$ & T3 \\
\hline \multicolumn{5}{|c|}{ Total bacterial count $\left(\mathrm{CFU} \times 10^{8} / \mathrm{mL}\right)$} \\
\hline $\mathbf{0}$ & 4.14 & 4.10 & 4.03 & 3.97 \\
\hline 1 & 4.19 & 4.16 & 4.12 & 4.10 \\
\hline 2 & 4.31 & 4.23 & 4.19 & 4.13 \\
\hline 3 & 4.52 & 4.34 & 4.23 & 4.19 \\
\hline \multicolumn{5}{|c|}{ Mould and yeast $\left(\mathrm{CFU} \times 10^{2} / \mathrm{mL}\right)$} \\
\hline $\mathbf{0}$ & ND & ND & ND & ND \\
\hline 1 & ND & ND & ND & ND \\
\hline 2 & ND & ND & ND & ND \\
\hline 3 & 1.12 & ND & ND & ND \\
\hline
\end{tabular}

Results in Table (5) show the logarithmic counts of Str. themophilus, $L b$. acidophilus and L. bularicus of buttermilk beverages. The obtained results cleared 
that, the fortification with (RBR) at any level led to promote the growth of all strains .It could be noticed that, Str. themophilus population is always higher than $L b$. acidophilus.( Rasic and Kurmann 1978) reviewed that Str. thermophilus grows faster at the beginning of lactic acid fermentation.

Table 5. Starter culture bacterial counts (log CFU/ $\mathrm{mL}$ ) of beverages buttermilk supplemented with different levels of (RBR) puree.

\begin{tabular}{|c|c|c|c|c|}
\hline $\begin{array}{l}\text { Storage } \\
\text { period } \\
\text { (week) }\end{array}$ & Control & T1 & T2 & T3 \\
\hline \multicolumn{5}{|c|}{ S. thermophiles $\left(\mathrm{CFU} \times 10^{6} / \mathrm{mL}\right)$} \\
\hline $\mathbf{0}$ & 8.00 & 8.14 & 8.21 & 8.25 \\
\hline 1 & 7.80 & 8.03 & 8.15 & 8.19 \\
\hline 2 & 7.51 & 7.81 & 8.02 & 8.08 \\
\hline 3 & 7.30 & 7.63 & 7.79 & 7.82 \\
\hline & \multicolumn{4}{|c|}{ Lactobacillus(CFU $\left.\times 10^{6} / \mathrm{mL}\right)$} \\
\hline 0 & 7.65 & 7.83 & 8.00 & 8.06 \\
\hline 1 & 7.40 & 7.60 & 7.72 & 7.76 \\
\hline 2 & 7.20 & 7.36 & 7.47 & 7.47 \\
\hline 3 & 6.60 & 6.92 & 7.05 & 7.10 \\
\hline
\end{tabular}

The survival of probiotics in fermented foods depend on several factors that may influence the ability of probiotics to survive and become active when entering the consumer's gastrointestinal tract (Heller, 2001). These include the physiological state of the probiotic organisms added (whether the cells are in logarithmic or the stationary growth phase), the physical conditions of the product storage, such as temperature, chemical composition of the product to which the probiotics are added (such as $\mathrm{pH}$, phenolic compounds, protein, dietary fiber, etc.), and finally the possible inter actions of the probiotics with the starter cultures, such as bacteriocin production, anti organism and also synergism . Several investigations have shown that bacteria from the logarithmic phase are much more susceptible to environmental stress than bacteria from the stationary phase (Heller, 2001).

\section{Total phenolic content and antioxidant activity (\%) :}

Table (6) presents the total phenolic compounds (PC) and antioxidant activity (AA) of buttermilk beverages supplemented with (RBR) puree when fresh or during the cold storage period for 3 weeks. The results show that, supplementing with (RBR) puree had significant increased $(P<0.001)$ in $(P C)$ and 
(AA) than the control. It could be attributed to the antioxidant activity of buttermilk which is well-know its high content of polar lipids, these polar lipids may also play a role in the superior ( AA) (Wong \& Kitts, 2003 and Conway et. al., 2013). Furthermore, (RBR) is well-known as a one of the radical crops with strongest (AA) and (PC) among the tested radica I crops (Fu et. al., 2011 and Oksuzet. al., 2015).

Generally, all( $P C)$ and $(A A)$ values tended to decrease with prolonged the cold storage period. This may be attributed to ( $P C$ ) is highly unstable compounds and under go numerous enzymatic and chemical reactions during food storage as reborted by ( Legrand 2005).

Table 6. Total phenolic content (equivalent $\mathrm{mg}$ Gallic acid/100gm) and antioxidant activity (\%) of buttermilk beverage supplemented with different levels of (RBR) puree (Average of three replicates).

\begin{tabular}{|c|c|c|c|c|}
\hline $\begin{array}{c}\text { Cold storage } \\
\text { period } \\
\text { (weeks) }\end{array}$ & \multicolumn{4}{|c|}{ Treatments } \\
\cline { 2 - 5 } & Control & T1 & T2 & T3 \\
\hline \multicolumn{5}{|c|}{ Total phenol } \\
\hline $\mathbf{0}$ & - & $21.50^{\mathrm{c}, \mathrm{a}}$ & $31.35^{\mathrm{b}, \mathrm{a}}$ & $40.21^{\mathrm{a}, \mathrm{a}}$ \\
$\mathbf{1}$ & - & $19.70^{\mathrm{c}, \mathrm{b}}$ & $29.10^{\mathrm{b}, \mathrm{b}}$ & $37.12^{\mathrm{a}, \mathrm{b}}$ \\
$\mathbf{2}$ & - & $17.15^{\mathrm{c}, \mathrm{c}}$ & $27.05^{\mathrm{b}, \mathrm{c}}$ & $36.01^{\mathrm{a}, \mathrm{c}}$ \\
\hline $\mathbf{3}$ & - & $15.41^{\mathrm{c}, \mathrm{d}}$ & $24.13^{\mathrm{b}, \mathrm{d}}$ & $34.02^{\mathrm{a}, \mathrm{d}}$ \\
\hline $\mathbf{0}$ & $21.30^{\mathrm{d}, \mathrm{a}}$ & $48.80^{\mathrm{c}, \mathrm{a}}$ & $50.12^{\mathrm{b}, \mathrm{a}}$ & $56.18^{\mathrm{a}, \mathrm{a}}$ \\
$\mathbf{1}$ & $19.56^{\mathrm{d}, \mathrm{a}}$ & $45.20^{\mathrm{c}, \mathrm{b}}$ & $46.09^{\mathrm{b}, \mathrm{b}}$ & $53.52^{\mathrm{a}, \mathrm{b}}$ \\
$\mathbf{2}$ & $15.35^{\mathrm{d}, \mathrm{a}}$ & $38.11^{\mathrm{c}, \mathrm{c}}$ & $40.41^{\mathrm{b}, \mathrm{c}}$ & $44.70^{\mathrm{a}, \mathrm{c}}$ \\
$\mathbf{3}$ & $10.51^{\mathrm{d}, \mathrm{a}}$ & $33.18^{\mathrm{c}, \mathrm{d}}$ & $32.01^{\mathrm{b}, \mathrm{d}}$ & $39.34^{\mathrm{a}, \mathrm{d}}$ \\
\hline
\end{tabular}

The letters before comma possess the factor of (RBR) level. While after comma possesses storage period, respectively. The means with the same letter at any position were not significantly different $(P>0.05)$

\section{Viscosity and whey syneresis of buttermilk beverages:}

It is obvious from the presented data in Table (7) that treatments, supplementing with (RBR) had significant differences $(P<0.001)$ in vicosity and syneresis values .

Also, it is clear from these data that viscosity and syneresis values, were increased significantly $(P<0.0001)$ in all treatments with the prolong of storage period. 
Table 7. Viscosity (cp) and Syneresisof buttermilk beverage supplemented with different levels of (RBR) puree (Average of three replicates).

\begin{tabular}{|c|c|c|c|c|}
\hline \multirow{3}{*}{$\begin{array}{c}\text { Cold storage } \\
\text { period (weeks) }\end{array}$} & \multicolumn{4}{|c|}{ Treatments } \\
\hline & Control & T1 & T2 & T3 \\
\hline & \multicolumn{4}{|c|}{ Viscosity (cp) } \\
\hline $\mathbf{0}$ & $\begin{array}{c}768 \\
d, d\end{array}$ & $862^{c, d}$ & $969^{b, d}$ & $\begin{array}{l}10 \\
12 \\
a, d\end{array}$ \\
\hline 1 & $\begin{array}{c}941 \\
d, c\end{array}$ & $\begin{array}{c}1198^{c} \\
, c\end{array}$ & $1309^{b, c}$ & $\begin{array}{l}14 \\
29 \\
a, c\end{array}$ \\
\hline 2 & $\begin{array}{l}109 \\
4^{\mathrm{d}, \mathrm{b}}\end{array}$ & $\begin{array}{c}1230^{c} \\
, \mathrm{~b}\end{array}$ & $1471^{b, b}$ & $\begin{array}{l}15 \\
98 \\
a, b\end{array}$ \\
\hline 3 & $\begin{array}{l}123 \\
8^{\mathrm{d}, \mathrm{a}}\end{array}$ & $\begin{array}{c}1499^{c} \\
, \mathrm{a}\end{array}$ & $1541^{\mathrm{b}, \mathrm{a}}$ & $\begin{array}{l}17 \\
80 \\
a, a\end{array}$ \\
\hline \multicolumn{5}{|c|}{ Syneress $(\mathrm{ml} / 100 \mathrm{~m})$} \\
\hline $\mathbf{0}$ & $\begin{array}{c}44^{a}, \\
c\end{array}$ & $40^{a, b, c}$ & $33^{b, c}$ & $\begin{array}{l}26 \\
c, c\end{array}$ \\
\hline 1 & $\begin{array}{c}50^{\mathrm{a}} \\
\mathrm{b}\end{array}$ & $46^{a, b, b}$ & $37^{a, b}$ & $\begin{array}{l}32 \\
c, b\end{array}$ \\
\hline 2 & $\begin{array}{c}55^{a}, \\
a\end{array}$ & $49^{a, b, a}$ & $42^{\mathrm{a}, \mathrm{a}}$ & $\begin{array}{l}37 \\
c, a\end{array}$ \\
\hline 3 & $\begin{array}{c}57^{a}, \\
a\end{array}$ & $51^{\mathrm{a}, \mathrm{b}, \mathrm{a}}$ & $45^{\mathrm{a}, \mathrm{a}}$ & $\begin{array}{l}41 \\
c, a\end{array}$ \\
\hline
\end{tabular}

The letters before comma possess the factor of (RBR) level. While after comma possesses storage period. The means with the same letter at any position did not significantly differ $(P>0.05)$.

It would be noticed that the treatment of butter milk beverage which content $15 \%$ (RBR) puree (T3) recorded the highest values of viscosity either when fresh or during storage compared with other treatments and control .Furthermore , viscosity increased significantly with the increasing the level of (RBR) puree .These results are in line with (Nelson, 2001). who reported that dietary fiber content (DF) which had desirable functional properties ,such as providing texture gelling, thickening.

It is clear from these data that increasing of protein content and dietary fiber in these treatments played a good role in increasing the viscosity because these components had the capability to form a viscosity solution, from gel and has its effect in binding water and work as a thickening agents (Jalili et al., 2000).

It is also clear from the presented data that supplemented butter milk beverage with (RBR) puree had significant effect on syneresis. Control treatment had a high value of whey separation either when fresh or during cold storage when compared with treatments . 


\section{Flow time.}

Regarding to the flow time are showed in Table (8) the results indicated that (T3) recorded a higher flow time values either when fresh or during cold storage period when compared with other treatments and control .Furthermore the results showed that the adding of (RBR) puree had significant effect on flow time (sce) and flow time increased with increasing the level of (RBR) puree .These results are agree with Nelson, 2001.

Table 8. Flow time (sec) of buttermilk beverage supplemented with different levels of (RBR) puree (Average of three replicates).

\begin{tabular}{|c|c|c|c|c|}
\hline \multirow{2}{*}{$\begin{array}{c}\text { Cold storage } \\
\text { period } \\
\text { (weeks) }\end{array}$} & \multicolumn{4}{|c|}{ Treatments } \\
\hline & Control & T1 & T2 & T3 \\
\hline $\mathbf{0}$ & $60^{\mathrm{d}, \mathrm{d}}$ & $80^{c, d}$ & $92^{b, d}$ & $101^{\mathrm{a}, \mathrm{d}}$ \\
\hline 1 & $63^{d, c}$ & $85^{c, c}$ & $97^{b, c}$ & $106^{a, c}$ \\
\hline 2 & $66^{\mathrm{d}, \mathrm{b}}$ & $88^{c, b}$ & $102^{b, b}$ & $110^{a, b}$ \\
\hline 3 & $75^{\mathrm{d}, \mathrm{a}}$ & $92^{\mathrm{c}, \mathrm{a}}$ & $108^{b, a}$ & $117^{\mathrm{a}, \mathrm{a}}$ \\
\hline
\end{tabular}

The means with the same letter at any position did not significantly differ $(P>0.05)$.

\section{Sensory evaluation:-}

Judging scores and its statistical analysis of beverages buttermilk with different levels of (RBR) during cold storage period are presented in Table(9).

The sensory evaluation revealed that butter milk supplemented with (RBR) was acceptable with best flavor, color, appearance, and total score .

Concerning the flavor score, the supplement with (RBR) beverages buttermilk up to $10 \%$ was significantly higher than all treatments. Increasing (RBR) level until $15 \%$, resulted to slightly darker color and the body became thickness which can explain the lower score of this treatment than control. The differences between the appearance score of beverages buttermilk fortified with $10 \%$ and control was not . The total score of beverages buttermilk which reflected the overall organoleptic quality of the product reveales that, the supplementation with beverages buttermilk at the level of $10 \%$ gained the best total scores compared with control or all other treatments. The sensory total score of beverages buttermilk which reflects the overall organoleptic quality of product reveal that, the supplementation of beverages buttermilk up to $10 \%$ in beverages buttermilk led to improve the total sensory quality versus than the control. 
Table 9. Sensory evolution of beverages buttermilk fortified with different levels of (RBR) (Average of three replicates ).

\begin{tabular}{|c|c|c|c|c|}
\hline \multirow{2}{*}{$\begin{array}{c}\text { Cold storage } \\
\text { period } \\
\text { (weeks) }\end{array}$} & \multicolumn{4}{|c|}{ Treatments } \\
\hline & Control & T1 & T2 & T3 \\
\hline \multicolumn{5}{|c|}{ colour (10) } \\
\hline 0 & $10^{\mathrm{ab}, \mathrm{a}}$ & $9^{a b, a}$ & $10^{\mathrm{a}, \mathrm{a}}$ & $8^{b, a}$ \\
\hline 1 & $9^{a b, a}$ & $9^{a b, a}$ & $10^{\mathrm{a}, \mathrm{a}}$ & $8^{b, a}$ \\
\hline 2 & $9^{a b, a}$ & $9^{a b, a}$ & $10^{\mathrm{a}, \mathrm{a}}$ & $8^{b, a}$ \\
\hline 3 & $8^{\mathrm{ab}, \mathrm{a}}$ & $8^{\mathrm{ab}, \mathrm{a}}$ & $10^{\mathrm{a}, \mathrm{a}}$ & $8^{b, a}$ \\
\hline \multicolumn{5}{|c|}{ Appearance (30) } \\
\hline $\mathbf{0}$ & $30^{\mathrm{a}, \mathrm{a}}$ & $30^{\mathrm{a}, \mathrm{a}}$ & $30^{\mathrm{aa}}$ & $30^{\mathrm{a}, \mathrm{a}}$ \\
\hline 1 & $30^{\mathrm{a}, \mathrm{a}}$ & $30^{\mathrm{a}, \mathrm{aaa}}$ & $30^{\mathrm{a}, \mathrm{a}}$ & $30^{\mathrm{a}, \mathrm{a}}$ \\
\hline 2 & $28^{\mathrm{a}, \mathrm{ab}}$ & $29^{\mathrm{a}, \mathrm{ab}}$ & $30^{\mathrm{a}, \mathrm{ab}}$ & $29^{\mathrm{a}, \mathrm{ab}}$ \\
\hline 3 & $26^{a, b}$ & $28^{\mathrm{a}, \mathrm{b}}$ & $29^{a, b}$ & $28^{\mathrm{a}, \mathrm{b}}$ \\
\hline \multicolumn{5}{|c|}{ Flavour (60) } \\
\hline $\mathbf{0}$ & $58^{\mathrm{b}, \mathrm{a}}$ & $59^{\mathrm{a}, \mathrm{a}}$ & $59^{a, a}$ & $59^{a, a}$ \\
\hline 1 & $57^{b, a}$ & $59^{\mathrm{a}, \mathrm{a}}$ & $59^{\mathrm{a}, \mathrm{a}}$ & $59^{a, a}$ \\
\hline 2 & $55^{\mathrm{b}, \mathrm{ab}}$ & $58^{\mathrm{a}, \mathrm{ab}}$ & $59^{a, a b}$ & $58^{\mathrm{a}, \mathrm{ab}}$ \\
\hline 3 & $52^{\mathrm{b}, \mathrm{ab}}$ & $57^{\mathrm{a}, \mathrm{ab}}$ & $58^{a, a b}$ & $58^{\mathrm{a}, \mathrm{ab}}$ \\
\hline & \multicolumn{4}{|c|}{ Total (100) } \\
\hline $\mathbf{0}$ & $98^{\mathrm{c}, \mathrm{a}}$ & $98^{\mathrm{b}, \mathrm{a}}$ & $99^{\mathrm{a}, \mathrm{a}}$ & $97^{\mathrm{b}, \mathrm{a}}$ \\
\hline 1 & $96^{c, a}$ & $98^{\mathrm{b}, \mathrm{a}}$ & $99^{\mathrm{a}, \mathrm{a}}$ & $97^{\mathrm{b}, \mathrm{a}}$ \\
\hline 2 & $92^{c, b}$ & $96^{\mathrm{b}, \mathrm{b}}$ & $99^{a, b}$ & $95^{\mathrm{b}, \mathrm{b}}$ \\
\hline 3 & $86^{c, c}$ & $93^{b, c}$ & $97^{a, c}$ & $94^{b, c}$ \\
\hline
\end{tabular}

The letters before comma possess the factor of (RBR)The means with the same letter at any position did not significantly diffelevel. While after comma possesses storage period. $r(P>0.05)$.

\section{REFERENCE}

1. American Public Health Association, APHA 1994. Standard method of the Examination of dairy products 16th Ed.., Washington, USA.

2. Arbuckle,W.S. 1986. Ice milk $4^{\text {th }}$ Ed.The AVI publishting Co. Inc.West port. Conneccticut,U.S.A

3. Associationof Official Analytical ChemistsAOAC 2007. Official method of analysis. (18 ${ }^{\text {th }}$ Ed. $)$, pp. 302-850. Benjamin Franklin Station Washington, D.C., USA.

4. Baumgartner, S.; Kelly E.; van der Made S., Berendschot T.; Husche C.; Lütjohann D. and Plat J. 2013. The influence of consuming an egg or an egg-yolk buttermilk drink for 12 weeks on serum lipids, inflammation, and liver function markers in human volunteers. Nutrition 29:1237.

5. Ceirwyn S. J. 1995. Analytical Chemistry of Foods. Part Iin book.p.135. 
6. Conway, V.; Couture P.,.Gauthier S.F, Pouliot Y. and Lamarche B. 2014. Effect of buttermilk consumption on blood pressure in moderately hypercholesterol emic men and women. Nutrition 30:116.

7. Conway, V.; Gauthier S.F. and Pouliot Y. 2013. Antioxidant activities of buttermilk proteins, whey proteins and their enzymatic hydrolyzates. J. Agric. Food Chem. 61:364.

8. Dave, R.I.and N.P. Shah. 1996. Evaluaton of media for selective enumeration of Streptococcus thermophilus, Lactobacillus delbrueckii ssp. bulgaricus, Lactobacillus acidophilus and bifidobacteria. J. Dairy Sci., 79: 1529.

9. Deka, D.; Rajor, R.B. and Patil, R. 1984. Studies on the formulation of Lassi (cultured drink) from soy bean and buttermilk. Egyptian J. Dairy Sci., 21: 291.

10. Delgado-Vargas F,Jiménez AR, Paredes-López O. 2000. Natural pigments: Carotenoids, anthocyanins, and betalains - characteristics, biosynthesis, processing, and stability. Critical Reviews in Food Science and Nutrition.;40:173289. DOI:10.1080/10408690091189257

11. El-dardiry A.I. ; Adel -Moniem , E. , Hagras ; Awad R.A. 2011. "Studies on some functional frozen dairy product". D. ph.Agricultue science .Dairy Science and Technology..1

12. Fu,L.;Xu,B.T.; Xu,X.R.; Gan,R.Y.; Zhang,Y.; Xia,E.Q.and Li,H.B. 2011. Antioxidant capacity ies and total phenolic contents of 62 fruits, Food Chemi., 129, 345.

13. Heller, K.J. 2001. Probiotic bacteria in fermented foods: product characteristics and starter organisms. Am. J. Clin. Nutr. 73(suppl): 374S.

14. Holt, D.L.; Wehling R.L. and Zeece M.G. 1988. Determination of native folates in milk and other dairy products by high-performance liquid chromatography. J. Chromatogr, 30:271.

15. Jalili, T.; Wildman, R. E. C. and Medeiros, D. M. 2000. Nutraceutical roles of dietary fiber. J.Nutra, Func. Med. Foods, 2, 19.

16. Jayaprakasha, K.; Singh, R. and Sakariah, K. 2001. Antioxidant activity of grape seed (Vitisvinifera) extracts on peroxidation models in vitro. Food Chem.,73:285.

17. Legrand, L.P. 2005. Poly (L-proline) interactions with flavon-3-ols Units: Influence of the molecular structure and the polyphenol / protein ratio. Food Hydro.20: 677.

18. Mehanna, N. M. and Mehanna, A. E. 1989. On the use of stabilizer for improving some properties of cow's milk yoghurt. Egypt. J. Dairy Sci., 17: 289. 
19. Nelson, A. L. 2001. High-Fiber Ingredients. Eagan press handbook series. St Paul, MN: Eagan Press, 2001.

20. Oksuz T.; Surek E.; Tacer-Caba Z. and Nilufer-Erdil D. 2015. Phenolic contents and antioxidant activities of persimmon and red beet jams produced by sucrose impregnation . Food Sci. Technol. 3: 1.

21. Ozcan, O. Kurtuldu, and B. Delikanli, "The development of cereal-based dairy products using $\beta$-glucan," Journal of Agricultural Faculty of Uludag University, vol. 27, pp. 87-96, 2013

22. Rasic, J.L. and J.A. Kurmann (Eds.) 1978. Yoghurt, Scientific Grounds, Technology, Manufacture and Preparations. pp. 17-68. Tech. Dairy Pub.House, Copenhagen, Denmark.

23. SAS, 1996. Statistical Analysis System. SAS user's guide. Satatistics. SAS Inst. Inc. Ed., Cary, NC, U.S.A.

24. Shimada, K.; Fujikawa, K.; Yahara, K.and Nakamura, T. 1992. Antioxidative properties of xanthan on the autoxidation of soybean oil in cyclodextrin emulsion. J.Agri. Food Chem.; 40: 945.

25. Vali, L., E. Stefanovits-Banyai, K. Szentmihalyi, H. Febel, E. Sardi, A. Lugasi, I. Kocsis, A. Blazovics, 2007. "Liver-protecting effects of table bee Beta vulgaris var Rubra) during ischemia-reperfusion," Nutrition 23, pp. 172178.

26. Wong, P.Y. and Kitts, D.D. 2003. Chemistry of buttermilk solid antioxidant activity. J. Dairy Sci., 86: 1541.

27. Vinderola C. G., Costa G. A., Regenhardt S., and J. A. Reinheimer, "Influence of compounds associated with fermented dairy products on the growth of lactic acid starter and probiotic bacteria," International Dairy Journal, vol. 12, pp. 579-589, 2002.

28. Wootton-Beard, P. C., A. Moran, and L. Ryan, 2011. Stability of the antioxidant capacity and total polyphenol content of 23 commercially available vegetable jucies before and after in vitro digestion as measured by FRAP, DPPH, ABTS and FolinCiocalteu methods. Food Research International, 44, 217-224. 


\section{ستدعيم اللبن الخض بالبنجر المهروس لأنتاج مشروب لبني متخمر}

محمد اسماعيل أحمد هاشم

$$
\text { قسم علم الاحياء الدقيقية - معهذ الانتاج الحيوانى - مركز البحوث الزراعية - دقى - جيزه - مصر }
$$

تهدف هذه الدراسة لانتاج مشروب من اللبن الخض المتخمر وذلك بتدعيمه بالبنجر

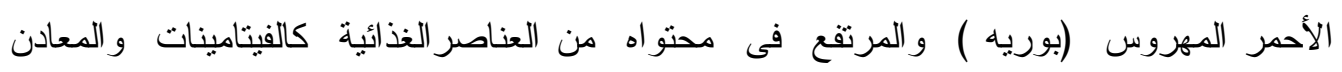
كما يحتوى ايضا علي نسبه عاليه من الالياف وكذلك مضادات الاكسدة منل الكاروتينات

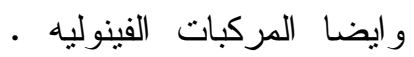

وتم في هذه الدراسة تدعيم اللبن الخض المتخمر بالبكتريا الحيوية ، البنجر

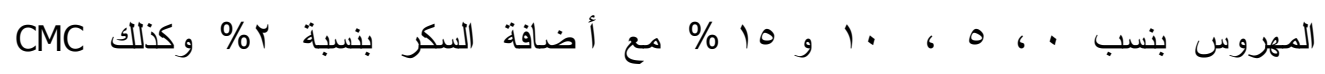

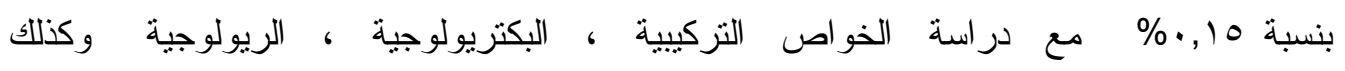

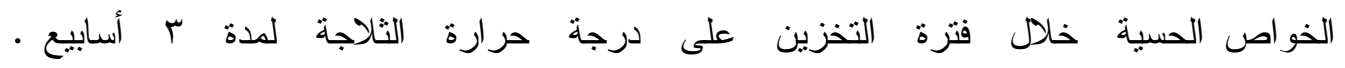
و أوضحت النتائج ان مشروب اللبن الخض المدعم بالبنجر المهروس تميز بارتفاع محتواه

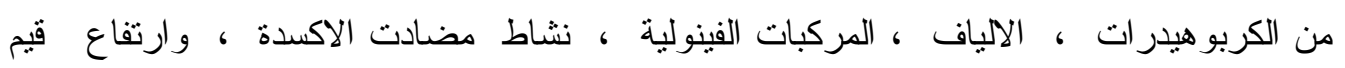

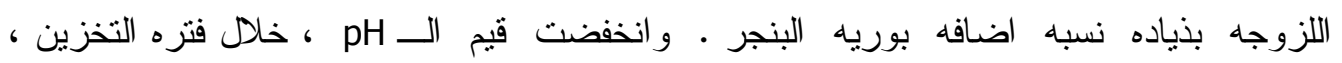

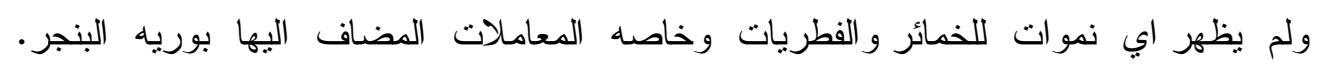
و اظهرت نتائج التحكيم الحسي ان المعاملات المضاف اليها بوريه البنجر اعطت افضل نتائج

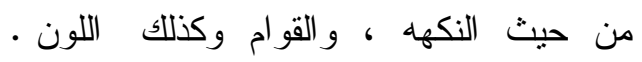
ومما سبق فانه يمكن إنتاج مشروب وظيفى من لبن خض متخمر مدعم بالبنجر

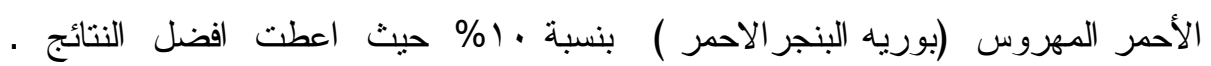


